\title{
Positive Lymph Node
}

National Cancer Institute

\section{Source}

National Cancer Institute. Positive Lymph Node. NCI Thesaurus. Code C27296.

The presence of metastatic cancer cells in a lymph node. 